\title{
DOES THE SERVICE TRADE OPENNESS MITIGATE REAL EXCHANGE RATE VOLATILITY?
}

\author{
Febrio Kacaribu*, Syahda Sabrina** and Teuku Riefky ${ }^{* * * *}$ \\ "Corresponding author. Faculty of Economics and Business, University of Indonesia, Jakarta, Indonesia. \\ Email: febrio.nathan@ui.ac.id \\ "* Faculty of Economics and Business, University of Indonesia, Jakarta, Indonesia. \\ Email: syahda.sabrina@ui.ac.id \\ ${ }^{* * *+}$ Faculty of Economics and Business, University of Indonesia, Jakarta, Indonesia. \\ Email: teuku_riefky7@hotmail.com
}

\begin{abstract}
This study examines the relationship between trade openness and exchange rate volatility. We use panel data of 52 countries and document trade openness has a negative and statistically significant effect on exchange rate volatility. The second explanatory variable considered in the model is money supply shock which is found to have a positive and statistically significant effect on exchange rate volatility. Our results survive a battery of robustness checks.
\end{abstract}

Keywords: Real exchange rate; Trade openness; Money supply shock; Panel data. JEL Classifications: F30; F32; F40.

\author{
Article history: \\ Received : October 19, 2019 \\ Revised : : August 24, 2020 \\ Accepted : September 02, 2020 \\ Available Online : June 30, 2021 \\ https://doi.org/10.21098/bemp.v24i2.1168
}




\section{INTRODUCTION}

Currency is an integral part of the modern economic system. As the medium of exchange, the economic activity needs money and most countries have their own currency in which its value is different from each other. One currency's relative value to another is reflected by its exchange rate. The value of one's exchange rate would determine the purchasing power of economic agents in one country of goods and services from others. Therefore, the volatility of the exchange rate would create turbulence in the economy, such as dampening the macroeconomic stability and harming the economic growth of a country (McKinnon et al., 1984; Hau, 2002; Aghion et al., 2009). Thus, an understanding of the determinants of exchange rate volatility provides valuable insights into the matter of macroeconomic stabilization. Previously, numerous studies have attempted to contribute to this area of literature and have formed the basis of trade openness as determinants of exchange rate volatility (Hau, 2000; Bleaney, 2008; Calderón, 2018). While studies on the relationship of goods trade and exchange rate volatility have been done quite extensively, the service counterpart of trade has not been addressed previously. Hence, in this paper, we aim to shed new light on this area of literature by assessing the impact of service trade openness in mitigating the real exchange rate volatility. Given the current condition of well-established international trade in goods whose flows dominated by developed countries, we see that it is rather difficult for developing countries to increase their trade openness in goods. Thus, we argue that the flows of services trade might be an alternative measurement for developing countries to achieve a more stable exchange rate.

This paper addresses the research hypothesis using the quarterly data of Real Exchange Rate (RER) and trade openness, both trade in goods and services from 52 countries for the sample period taken from 2005Q1 to 2019Q1. We employ panel data regression, which also been used by previous studies in this area of literature. The combination of the wide-range variability in cross-country samples with the multiple time series data is exercised in the spirit of enhancing the results of the study. However, this methodology alone is not enough to tackle the endogeneity issues whose occurrence is highly possible as the volume of trade might be significantly affected by RER volatility (Broda and Romalis, 2011). Hence, we also employ the instrumental variable (IV) approach to re-evaluate the simultaneous relationship between trade openness and RER volatility. We treat the land area of each country as the instrumental variable that is believed to affect the macroeconomic variable from no other channel rather than trade openness.

Our main contribution to the literature is by addressing the impact of openness in the structure of trade, which are the goods and services trade. The empirical analysis shows that both trades of goods and services have a significant negative effect on RER volatility. However, we must consider that services are complementary rather than a substitute for goods trade, particularly to the manufacturing trade sector. Landefeld (1987) has shown that higher export of manufacturing goods also increases the trade of services. Given this stance and considering the trend of lower global manufacturing trade, utilizing another services trade excluded from the manufacturing-related trade might be relevant in the discussion of finding alternative measurement in mitigating exchange rate volatility for developing countries. Also, in general, the result of the regression 
analysis empirically confirms that trade openness matters for RER stabilization, as previously mentioned by Hau (2002), Bleaney (2008), and Calderón (2018). We also discard the endogenous issue from the volatility risk to the trade openness channel by using the IV approach.

\section{Figure 1.}

\section{Non-Manufactured Related Services Trade}

This figure presents the distribution of non-manufactured related services trade based on following disaggregate services categories: travel and passenger transport, information and communication (ICT), Intellectual property charges, financial, government procurement, construction, and other services. The total value of non-manufactured related services for HI countries and MI countries are USD 6.2 trillion and USD 0.9 trillion, respectively. Data is collected from the World Bank; however, the disaggregation components are calusted by the authors.

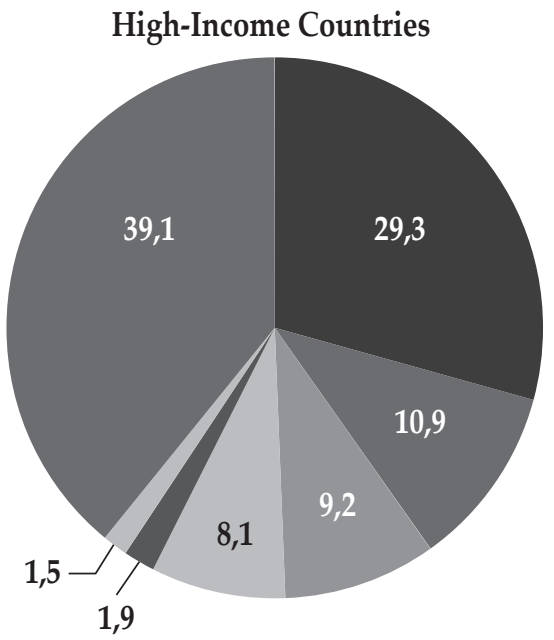

Travel and Passanger Transport Intellectual Property Charges

Govt Procurement

Other Services

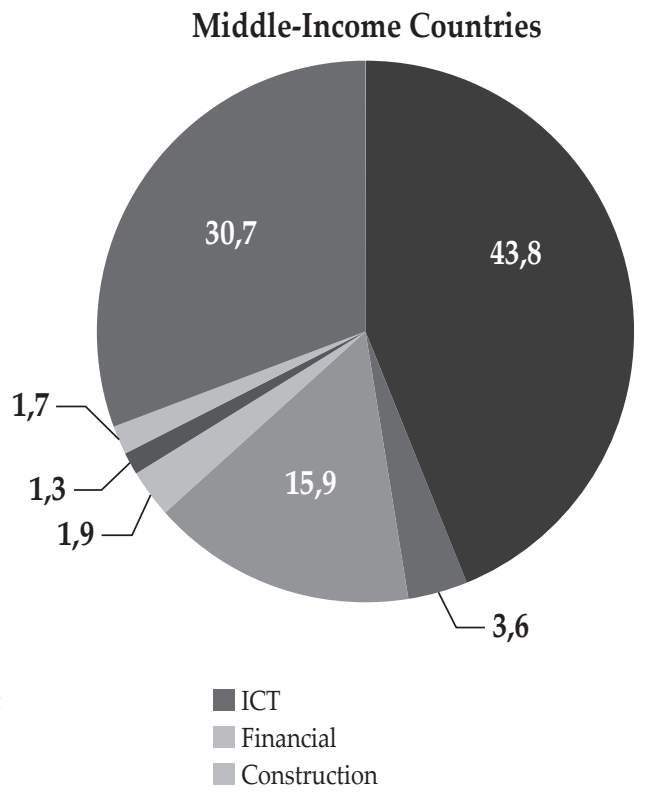

Middle-Income Countries

Construction

This study also analyses the overall services trade and non-manufacturing related services trade. By using the latest figure of services trade data from the selected 52 countries, the accumulation value of non-manufacturing related services amounts to USD7.1 trillion in 2018. The non-manufacturing related services are highly contributed by travel and passenger transport activities. The share of travel and passenger transport in middle-income countries is higher than the high-income countries (Figure 1). The posture is more likely influenced by the large percentage of travel and passenger transport services in the high tourism demand countries, such as Thailand, Turkey, Mexico, Malaysia, and Indonesia. Nevertheless, to the best of our knowledge, there are no previous studies addressing how the openness in non-manufacturing related services might have an impact on real exchange rate volatility. By separating the services trade into non-manufacturing related services in this study, the result of our empirical analysis shows that non-manufacturing related services are a better estimator in stabilizing RER volatility compared with 
the overall trade in services. However, the significance is only found in middleincome countries, while the trade in goods might be a better explanatory variable of exchange rate stability in high-income countries. It can be explained by the higher domination of trade in goods in high-income countries compared to those middle-income group.

Besides the trade openness, our empirical analysis also covers the other significant explanatory variables of real exchange rate volatility, such as monetary shocks as represented by the money supply volatility, the financial openness, exchange rate index, nominal GDP, and the current account balance. Our results are consistent with the overshooting effect that concludes the monetary shocks give a higher real exchange rate volatility. Further, the financial account, which is measured as the ratio of foreign liabilities to GDP, has no significant result in real exchange rate volatility. There are a number of factors that might affect the result, including the wide variability information in financial liabilities account, the high currency exposure to the international financial instruments, as well as relatively small portion of financial openness compared to the trade openness, which all in all contribute to statistically insignificant impact of financial openness on RER volatility. However, as our next contribution to the literature, this study finds that the fluctuations of the real exchange rate are getting lower as the country's economic size and development perform better.

This study also finds that both goods and non-manufacturing related services openness are found as a significant contributor in reducing the fluctuations of the real exchange rate during the pre- and post- Global Financial Crisis (GFC) in 20082009. The only difference with the previous sample analysis is the impact of money supply shocks to RER volatility is lower after the turbulent time since the market has shifted to a more risk-averse stance than they were before. Like the post-GFC result, the lower effect of money supply shock to the RER volatility is also found in Inflation Targeting Framework (ITF)-based countries compared to the non-ITF countries. More stable inflation fluctuations help the ITF countries to dampen the impact of monetary shocks on RER volatility. However, since the impact of money supply shock on RER volatility is more pronounce in non-ITF countries, nonmanufacturing related services trade is found to give a more volatile RER rather than stabilizing the fluctuations. Our last contribution is that this study finds that non-manufacturing related services might be an alternative measurement to dampen the RER volatility in developing countries that implement the ITF.

The remaining sections proceed as follows. Section II presents some theoretical and empirical model built upon this topic. Section III describes the methodology and data used in this study. Section IV discusses the empirical results, and finally, section $\mathrm{V}$ provides conclusions of the study.

\section{THEORETICAL MODEL}

A. Theoretical Insights

Countries around the world have been economically more integrated in the past decades, as shown by a bigger trade and financial openness. Despite the numerous advantages, rising integration between countries has been perceived as a factor associated with higher exchange rate fluctuations. There are various 
methods in determining exchange rate volatility, which commonly grouped into two classifications, monetary approach and non-monetary approach. While the monetary approach used to estimate exchange rate volatility by some monetary variables such as money supply and inflation, the non-monetary method attempts to tie some real sectors into the estimation.

From the monetary approach, Dornbusch (1976) finds that any monetary shocks would lead to an overshooting of nominal and real exchange rate. It is happened due to the existence of slower adjustment in goods market relative to the financial market. Thus, any shocks of monetary or financial prices will bring a higher fluctuation on the real exchange rate compared to the impact of the stickiness of good prices. The volatility of exchange rate increases due to greater sensitivity to financial prices shock (the exchange rate and interest rate) compared to the prices stickiness of goods as the latter taking longer time to adjust (Taylor, 1995). Also, Bergin and Feenstra (2001) show theoretically and empirically that the potential of the large and persistent impact of monetary or financial shocks on real exchange rate volatility.

Numerous empirical studies have applied the monetary approach. Morana (2009) finds a significant linkage between macroeconomic variables and exchange rate volatility, which is particularly involving inflation and money supply shocks to the study. Similarly, the study by Grydaki and Fountas (2009) also attempt to determine the exchange rate volatility under monetary and inflationary shocks and has shown a significant relationship between the shocks and exchange rate volatility. However, the study by Meese and Rogoff (1983) shows that the fluctuations of the exchange rate are not solely determined by monetary or financial shocks. Rogoff (1999) finds that even though inflation has already stabilized at a lower level in some developed countries since 1980 - 1990, their exchange rates are still significantly volatile. These findings have made researchers wondering whether overshooting theory, which is mostly addressed in monetary approach, already reflects all the motions of exchange rate or not.

In the spirit of tracing another approach to analyze the exchange rate movement, Hau (2000) elaborates the New Open Economy Macroeconomics theory by Obstfeld \& Rogoff (1995) to find the non-monetary determinants of exchange rate volatility. Assuming the law of one price, Hau (2000) shows that there will be a quick adjustment process on the prices of the goods due to an increasing number of imported goods in an open economy. On the other hand, closed economies will experience an increase in real exchange rate volatility along with money supply shocks. The reduced frictions or transaction costs in international goods and services trade due to the trade openness would consequently either limit or worsen the impact of nominal or real shocks on RER (Obstfeld and Rogoff, 1995, 1996; Hau, 2000, 2002).

Even though the negative linkage between trade openness and real exchange rate volatility is well-defined theoretically and empirically, there is still lack of evidence on how the structures of trade openness (goods vs services) affect real exchange rate volatility. Calderón (2018) finds that trade openness in manufacturing goods helps reducing real exchange rate volatility, while non-manufacturing goods trade relates to higher real exchange rate volatility. The findings are unfavourable for non-manufacturing producers' countries which might depend on their economy 
to the natural resources. As the price of commodity goods is relatively slow to adjust with the trade, the non-manufacturing dependence country should use another tool in mitigating real exchange rate volatility. However, there is still no literature that points out the role of other than goods trade openness, which is service trade, to alleviate the exchange rate volatility.

Service trade openness is still relatively smaller than the goods trade. However, the growth in services trade openness is accelerating. The rapid technological development of transportation, telecommunication, computer, and information services have resulted in significant cross border exchanges of services. Liberalization in telecommunication and financial services are found to have a positive impact on economic growth (Mattoo et al., 2001). Also, services related to tourists' activities such as travel, transportation, and recreational services are significantly influenced economic growth in both developed and developing countries (Balaguer and Cantavella-Jorda, 2002; Seetanah, 2011; Salmani et al., 2014). In-bound and out-bound tourists' play a significant role in increasing foreign exchange earnings (Lunderberg et al., 1995). Services related to tourism activities will also lead to a higher amount of imported goods or services in the destination countries as they tend to fulfil the tourists' needs of familiar products with their own countries (Kulendran and Wilson, 2000 and Khan et al., 2005). On the other hand, Çalışkan, et al. (2019) finds that tourist arrivals are related to exports only in the short term; however, in the long run, there is a positive relationship between tourism activities and imports. Even though the empirical studies show different results between the impact of services in tourism activities on exports or imports, higher non-manufacturing related services are clearly associated with a more open economy. Nevertheless, no existing literature that shows how these services trade contributes to the lower real exchange rate volatility.

\section{DATA AND METHODOLOGY}

\section{A. Data}

We use quarterly data for 52 countries over the period 2005Q01 to 2019Q01. These 52 countries are divided into two income-based groups, namely High-Income (HI) countries and Middle Income (MI) countries. There are $37 \mathrm{HI}$ countries (namely Australia, Austria, Belgium, Canada, Chile, Croatia, Cyprus, the Czech Republic, Denmark, Estonia, Finland, France, Germany, Greece, Hungary, Iceland, Israel, Italy, Japan, South Korea, Latvia, Lithuania, the Netherlands, New Zealand, Norway, Poland, Portugal, Romania, Saudi Arabia, Slovakia, Slovenia, Spain, Sweden, Switzerland, the United Kingdom, and the United States) and $15 \mathrm{MI}$ countries (namely Argentina, Bulgaria, Brazil, China, Colombia, India, Indonesia, Malaysia, Mexico, Peru, Philippines, Russian Federation, South Africa, Thailand, and Turkey). The list of countries appears in Table 1.

We use Real Exchange Rate Volatility (RERV) as the dependent variable. To capture all possible trade activities, the Real Effective Exchange Rate (REER) is chosen as a proxy for real exchange rate. REER is sourced from the Bank for International Settlements (BIS). Besides providing time-varying trade weights in order to match the rapidly changing patterns between countries, this data also has 
a broader basket weight. ${ }^{1}$ We use standard deviation of year-on-year percentage change in $R E E R$ as a proxy for $R E R V$ as proposed in Calderón (2018). In order to trace the fittest volatility, the percentage change of the $R E E R$ are averaged of 3-month REER over a 9-quarter window calculated using a monthly REER database. We choose the 9-centered moving average instead of the uncentered moving average at time $t+9$ to avoid capturing only the trend at the end of the sampled window. Hence, the real exchange rate volatility is calculated as follows:

$$
\begin{aligned}
R E R V & =\left[\frac{1}{T} \sum_{t}\left(R E_{t+9}-\overline{R E_{t}}\right)^{2}\right]^{1 / 2} \\
\text { where, } & R E=\frac{R E E R_{t}-R E E R_{t-4}}{R E E R_{t-4}} .
\end{aligned}
$$

Additionally, we have used two key explanatory variables, namely Trade Openness (TO) and Money Supply Shocks (MSV) and four control variables, namely Exchange Rate Regime Index $(E R)$, financial openness measure as a ratio of foreign liabilities to GDP (FO), norminal GDP (GDP), current account balance measured as percentage of GDP $(C A B)$. We provide detail information, such as data source and full data description of all variables used in this study in Table 2.

Table 1.

\section{List of Countries}

This table list 37 High-Income (HI) and 15 Middle-Income (MI) countries considered in this study. ${ }^{*}$ denotes lower MI countries and the remaining are upper MI countries.

\begin{tabular}{lcc}
\hline HI countries & & MI countries \\
\hline Australia & Japan & Argentina \\
Austria & South Korea & Brazil \\
Belgium & Latvia & Bulgaria \\
Canada & Lithuania & China \\
Chile & Netherlands & Colombia \\
Croatia & New Zealand & India* \\
Cyprus & Norway & Indonesia* \\
Czech Republic & Poland & Malaysia \\
Denmark & Portugal & Mexico \\
Estonia & Romania & Peru \\
Finland & Saudi Arabia & Philippines* \\
France & Slovakia & Russian Federation \\
Germany & Slovenia & South Africa \\
Greece & Spain & Thailand \\
Hungary & Sweden & Turkey \\
Iceland & Switzerland & \\
Ireland & United Kingdom & \\
Israel & United States & \\
Italy & & \\
\hline
\end{tabular}

1 The trade weighted basket of BIS EER has been broadened into 61 economies due to the rising importance of the emerging economies in Asia, Central and Eastern Europe and Latin America, see Klau (2006) 
Table 2.

Data Description

This table provides detail data description of all variables considered in this study.

\begin{tabular}{|c|c|c|c|}
\hline Variable & Description & Source & $\begin{array}{l}\text { Expected } \\
\text { Sign }\end{array}$ \\
\hline REER & Relative real exchange rate & & \\
\hline RERV & $\begin{array}{c}\text { Real exchange rate volatility: } \\
R E R V=\left[\frac{1}{T} \sum_{t}\left(R E_{t+9}-\overline{R E_{t}}\right)^{2}\right]^{1 / 2} \\
\text { where, } R E=\frac{R E E R_{t}-R E E R_{t-4}}{R E E R_{t-4}}\end{array}$ & $\begin{array}{l}\text { Authors } \\
\text { calculation }\end{array}$ & $\begin{array}{l}\text { Dependent } \\
\text { variable }\end{array}$ \\
\hline ER & Exchange rate regime index & Chinn-Ito Index & - \\
\hline$I M P$ & Total imports of goods and services & IFS & \\
\hline EXP & Total imports of goods and services & IFS & \\
\hline IoG & Total imports of goods & IFS & \\
\hline EoG & Total exports of goods & IFS & \\
\hline IoS & Total imports of services & IFS & \\
\hline EoS & Total imports of services & IFS & \\
\hline TO & $\begin{array}{l}\text { Trade openness: ratio of export \& import of goods } \\
\text { and services to GDP : (imports + exports)/nominal } \\
\qquad \text { GDP }\end{array}$ & $\begin{array}{l}\text { Authors } \\
\text { calculation }\end{array}$ & - \\
\hline GO & $\begin{array}{l}\text { Goods openness: ratio of export \& import of goods } \\
\text { to GDP: }(I o G+E o G) / \text { nominal GDP }\end{array}$ & $\begin{array}{l}\text { Authors } \\
\text { calculation }\end{array}$ & - \\
\hline SO & $\begin{array}{l}\text { Services openness: ratio of export \& import of } \\
\text { services to GDP: (imports of services+exports of } \\
\text { services)/nominal GDP }\end{array}$ & $\begin{array}{l}\text { Authors } \\
\text { calculation }\end{array}$ & - \\
\hline$F O$ & $\begin{array}{c}\text { Financial openness: ratio of foreign liabilities (FDI, } \\
\text { Portfolio, debt and derivatives) to GDP }\end{array}$ & $\begin{array}{l}\text { Authors } \\
\text { calculation }\end{array}$ & - \\
\hline M2 & $\begin{array}{l}\text { Money supply that includes cash, checking } \\
\text { deposits, and easily convertible near money. }\end{array}$ & CEIC database & \\
\hline MSV & $\begin{array}{c}\text { Money supply shocks: } \\
M S V=\left[\frac{1}{T} \sum_{t}\left(M S_{t+9}-\overline{M S_{t}}\right)^{2}\right]^{1 / 2} \\
\text { where, } M S=\frac{M 2_{t}-M 2_{t-4}}{M 2_{t-4}}\end{array}$ & $\begin{array}{l}\text { Authors } \\
\text { calculation }\end{array}$ & + \\
\hline GDP & $\begin{array}{l}\text { One period lag of nominal GDP (in natural } \\
\text { logarithm) }\end{array}$ & IFS & - \\
\hline$C A B$ & Current account balance (as \% GDP) & IFS & - \\
\hline Non-M & $\begin{array}{l}\text { Non-manufactured related services openness: the } \\
\text { ratio of export \& import of Non-Manufactured } \\
\text { related services to GDP (e.g. transport, ICT, } \\
\text { financial services). }\end{array}$ & $\begin{array}{l}\text { Authors } \\
\text { calculation }\end{array}$ & - \\
\hline Equity & $\begin{array}{l}\text { Equity related foreign liabilities: the ratio of equity } \\
\text { related foreign liabilities (FDI) to GDP }\end{array}$ & $\begin{array}{l}\text { Authors } \\
\text { calculation }\end{array}$ & - \\
\hline Non-equity & $\begin{array}{l}\text { Non-equity related foreign liabilities: the ratio of } \\
\text { non-equity related foreign liabilities (portfolio) to } \\
\text { GDP }\end{array}$ & $\begin{array}{l}\text { Authors } \\
\text { calculation }\end{array}$ & - \\
\hline
\end{tabular}


B. Methodology

To examine the relationship between $T O$ and exchange rate volaitiy, we first estimate the following benchmark regression model:

$$
R E R V_{i t}=\alpha_{0}+\beta_{1} T O_{i t}+\beta_{2} M S V_{i t}+\varepsilon_{i t}
$$

Here, $R E R V$ represents exchange rate volatility, TO represents trade openness, and MSV represents money supply shock. We follow as Hau (2002) and Calderón (2018) and estimate Equation (1) using four approaches, pooled ordinary least squares (pooled OLS), fixed effects, random effects, and instrumental variable (IV) estimations. These various estimation approaches are used in order to control for endogeneity problem in our empirical model.

In addition, we re-estimate Equation (1) by including four control variables, namely Exchange rate Regime index $(E R)$, Financial Openness $(F O)$, nominal GDP $(G D P)$, and Current Account Balance $(C A B)$. These control varaibles are added one at a time in the benchmark model. Therefore, we further estimate following four regression models using panel pooled OLS approach:

$$
\begin{aligned}
& R E R V_{i t}=\alpha_{0}+\beta_{1} T O_{i t}+\beta_{2} M S V_{i t}+\beta_{3} E R_{i t}+\varepsilon_{i t} \\
& R E R V_{i t}=\alpha_{0}+\beta_{1} T O_{i t}+\beta_{2} M S V_{i t}+\beta_{3} E R_{i t}+\beta_{4} F O_{i t}+\varepsilon_{i t} \\
& R E R V_{i t}=\alpha_{0}+\beta_{1} T O_{i t}+\beta_{2} M S V_{i t}+\beta_{3} E R_{i t}+\beta_{4} F O_{i t}+\beta_{5} G D P_{i t}+\varepsilon_{i t} \\
& R E R V_{i t}=\alpha_{0}+\beta_{1} T O_{i t}+\beta_{2} M S V_{i t}+\beta_{3} E R_{i t}+\beta_{4} F O_{i t}+\beta_{5} G D P_{i t}+\beta_{6} C A B_{i t}+\varepsilon_{i t}
\end{aligned}
$$

\section{EMPIRICAL FINDINGS}

\section{A. Preliminary Analysis}

We begin by discussing descriptive statistics of data from Table 3. More specifically, we report mean, maximum, minimum, Standard Deviation (SD) of three main variables (namely $R E R V, T O$, and $M S V$ ). Our data is categorised into three groups, all 52 countries, HI countries, and MI countries. The mean RERV and MSV are reported highest for MI countries compared to HI countries. More specifically, the mean RERV and MSV is 3.78 and 4.01 for MI countries and 2.33 and 3.02 for $\mathrm{HI}$ countries, respectively. We also note that the volatility of $R E R V$ and $M S V$ is highest in the case of MI countries compared to HI countries. Even though there is no significant difference between $M S V$ in $\mathrm{HI}$ and MI countries, the MI countries experience a very volatile exchange rate compared to HI countries.

Additionally, we note that mean $\mathrm{TO}$ is found to be highest in the case of $\mathrm{HI}$ countries (107.82) compared to MI countries (68.53). In other words, we note that the mean TO in HI countries is almost twice as high as the mean of TO in MI countries. Reinforced with TO, we can see that MI countries whose average openness is relatively very low tend to have a more volatile exchange rate. In contrast, HI countries with high openness have a comparatively stable exchange rate. Nevertheless, there is no significant difference between their monetary shocks. Thus, it can be pre-concluded that high TO might dampen the exchange rate volatility. 
Table 3.

\section{Descriptive Statistics}

This table presents descriptive statistics. Specifically, we report mean, maximum, minimum, and Standard Deviation (SD) of main variables used in the study. Additionally, we have considered descriptive statistics of variables in two income-based country groups, namely HI countries and MI countries. All variables are defined in Table 2.

\begin{tabular}{|c|c|c|c|}
\hline & All & HI countries & MI countries \\
\hline \multicolumn{4}{|c|}{ Panel A: RERV } \\
\hline Mean & 2.75 & 2.33 & 3.78 \\
\hline Maximum & 13.47 & 11.11 & 13.47 \\
\hline Minimum & 0.33 & 0.33 & 0.64 \\
\hline SD & 2.05 & 1.80 & 2.23 \\
\hline \multicolumn{4}{|c|}{ Panel B: TO } \\
\hline Mean & 96.48 & 107.82 & 68.53 \\
\hline Maximum & 395.06 & 395.06 & 206.82 \\
\hline Minimum & 17.22 & 17.22 & 18.72 \\
\hline Std. Dev. & 63.20 & 67.56 & 38.68 \\
\hline \multicolumn{4}{|c|}{ Panel C: $M S V$} \\
\hline Mean & 3.30 & 3.02 & 4.01 \\
\hline Maximum & 47.35 & 36.07 & 47.4 \\
\hline Minimum & 0.10 & 0.15 & 0.10 \\
\hline Std. Dev. & 4.05 & 3.25 & 5.49 \\
\hline \multicolumn{4}{|c|}{ Panel D: GO } \\
\hline Mean & 72.51 & 78.95 & 56.62 \\
\hline Maximum & 312.01 & 312.01 & 179.01 \\
\hline Minimum & 12.07 & 12.07 & 14.76 \\
\hline Std. Dev. & 44.87 & 47.66 & 31.99 \\
\hline \multicolumn{4}{|c|}{ Panel E: SO } \\
\hline Mean & 23.98 & 28.87 & 11.92 \\
\hline Maximum & 208.41 & 208.41 & 35.11 \\
\hline Minimum & 3.61 & 4.42 & 3.61 \\
\hline Std. Dev. & 25.56 & 28.49 & 7.67 \\
\hline Number of Observations & 2,756 & 1,961 & 795 \\
\hline Number of Countries & 52 & 37 & 15 \\
\hline
\end{tabular}

Looking deeper into the composition of $T O$, we provide a descriptive analysis of trade openness in goods and services. While HI countries are occupied with excessive trade openness both in goods $(\mathrm{GO})$ and services $(\mathrm{SO})$ trade, MI countries' goods openness is relatively low The spread between mean SO of MI and HI countries is more than double compared to the spread between mean GO in the case of MI and $\mathrm{HI}$ countries. This description may imply that a relatively muted real exchange rate volatility in $\mathrm{HI}$ countries is contributed by the services trade openness. However, this conclusion is still descriptive and needs to be examined using an empirical model.

Next, we also conduct panel unit root test in order to examine the stationarity of our main variables. We have used Levin, Lin and Chu panel unit root test to examine the null hypothesis of unit root and report these results in Table 4. Our 
results indicate, we comfortably reject the null hypothesis of unit root in the case of all variables at least at 5\% significance level. In other words, we confirm that all variables follow stationary process.

Table 4.

\section{Unit Root Test Results}

This table reports Levin-Lin-Chu panel unit root test results. The Levin-Lin-Chu panel unit root test examines the null hypothesis of unit root (non-stationary) in data series. All variables are defined in Table 2.

\begin{tabular}{lccc}
\hline Variables & AR Parameter & Adjusted $t$-statistics & $p$-value \\
\hline TO & Common & -6.9356 & $>0.05$ \\
MSV & Common & -1.331 & $>0.05$ \\
ER & Common & -1.306 & $>0.05$ \\
FO & Common & -1.753 & $>0.05$ \\
GDP & Common & -1.316 & $>0.05$ \\
CAB & Common & -1.759 & $>0.05$ \\
\hline
\end{tabular}

\section{B. Main Findings}

In this section, we discuss our main findings obtained by estimating Equations (2) - (6). First, we estimate our benchmark model, depicted by Equation (2), using four estimation techniques, namely pooled OLS, fixed effects, random effects and IV estimation approach. We must acknowledge that there is a potential bi-directional causal relationship between $T O$ and exchange rate volatility. There are number of studies which document that exchange rate volatility can hamper economic growth due to the fact that the decline in the investment will have a negative effect on economic growth (see Serven, 1998; Bleaney and Greenway, 2001; Aghion et al., 2009). Also, it is shown that the volume of trade might be significantly affected by the exchange rate volatility (see Broda dan Romalis, 2011). Thus, to address the endogeneity problem, we incorporate the IV estimation approach in addition to commonly used techniques such as pooled OLS, random effects and fixed effects panel models. More specifically, we use country's geography figure, which is the land area, as an instrumental variable in IV estimation approach.

These results are reported in Panel A of Table 5. We find that, irrespective of the estimation technique we use, TO has a negative and statitcally singfnicant while $M S V$ has a positive and statiscally significant effect on exchange rate volatility. Our findings are consistent with theoretical framework discussed earlier which states that exchange rate volatility due to the higher monetary shocks will be lower in a country with high $T O$.

Next, we read results from Panel B. Here, we include four control variables (namely $E R, F O, G D P$, and $C A B$ ), one at a time, in our main regeresion model. First, we include ER (see Equation 3 ) as a control variable in the benchmark model, followed by $E R$ and $F O$ (see Equation 4), ER, TO, and GDP (see Equation 5), and ER, TO, GDP and CAB (see Equation 6). We use pooled OLS estimator for these four additional models. Our findings are consistent with results obtained using benchmark model where we find $T O$ has a positive and MSV has a negative and statistically significant effect on exchange rate volatility. In orther words, our findings remain same irrespective of the use of model specification and estimation techniques. 
Table 5.

\section{Exchange Rate Volatility and Trade Openness Relationship}

In Panel A of this table, we report results from our baseline empirical model. The empirical model has a following form: $R E R V_{i t}=\alpha_{0}+\beta_{1} T O_{i t}+\beta_{2} M S V_{i t}+\varepsilon_{i t}$. We extend our baseline model by including other four control variables, namely $E R, F O, G D P$, and $C A B$. We include these control variables in the main model, one at a time, and therefore, we estimate another four regression models (Equations (3) - (6)) and report results in Panel B. We report estimated coefficients and its corresponding t-statistics in parenthesis. All variables are defined in Table 2. ${ }^{* * *},{ }^{* *}$, and ${ }^{*}$ denote statistical significance at the $1 \%, 5 \%$, and $10 \%$, respectively.

\begin{tabular}{|c|c|c|c|c|}
\hline & Pooled OLS & Fixed Effects & Random Effects & IV Estimation \\
\hline \multicolumn{5}{|c|}{ Panel A: Main model without control variables } \\
\hline Constant & $\begin{array}{c}3.5545^{* * *} \\
{[50.72]}\end{array}$ & $\begin{array}{c}2.8441^{* * *} \\
{[21.41]}\end{array}$ & $\begin{array}{c}2.9951^{* * *} \\
{[14.05]}\end{array}$ & $\begin{array}{c}4.5494^{* * * *} \\
{[44.36]}\end{array}$ \\
\hline TO & $\begin{array}{c}-0.0124^{* * *} \\
{[-22.99]}\end{array}$ & $\begin{array}{c}-0.0040^{* * * *} \\
{[-3.04]}\end{array}$ & $\begin{array}{c}-0.0056^{* * *} \\
{[-4.66]}\end{array}$ & $\begin{array}{c}-0.0222^{* * *} \\
{[-24.62]}\end{array}$ \\
\hline MSV & $\begin{array}{c}0.1189^{* * * *} \\
{[14.13]}\end{array}$ & $\begin{array}{c}0.0898^{* * *} \\
{[12.30]}\end{array}$ & $\begin{array}{c}0.0906^{* * *} \\
{[12.44]} \\
\end{array}$ & $\begin{array}{c}0.1037^{* * *} \\
{[11.56]} \\
\end{array}$ \\
\hline$R^{2}$ & 0.2253 & 0.1956 & 0.2138 & 0.1322 \\
\hline \multicolumn{5}{|c|}{ Panel B: Pooled OLS regression model with control variables } \\
\hline & $\mathrm{Eq}(3)$ & $\mathrm{Eq}(4)$ & $\mathrm{Eq}(5)$ & $\mathrm{Eq}(6)$ \\
\hline Constant & $\begin{array}{c}4.8206^{* * *} \\
{[71.34]}\end{array}$ & $\begin{array}{c}4.8205^{* * *} \\
{[71.33]}\end{array}$ & $\begin{array}{c}3.0906^{* * *} \\
{[10.94]}\end{array}$ & $\begin{array}{c}3.5407^{* * *} \\
{[12.01]}\end{array}$ \\
\hline TO & $\begin{array}{c}-0.0037^{* * *} \\
{[-7.24]}\end{array}$ & $\begin{array}{c}-0.0036^{* * *} \\
{[-7.18]}\end{array}$ & $\begin{array}{c}-0.0019^{* * * *} \\
{[-3.25]}\end{array}$ & $\begin{array}{c}-0.0012^{* *} \\
{[-1.97]}\end{array}$ \\
\hline MSV & $\begin{array}{c}0.0972^{* * *} \\
{[13.96]}\end{array}$ & $\begin{array}{c}0.0973^{* * *} \\
{[13.98]}\end{array}$ & $\begin{array}{c}0.1061^{* * *} \\
{[15.06]}\end{array}$ & $\begin{array}{c}0.1048^{* * *} \\
{[14.93]}\end{array}$ \\
\hline$E R$ & $\begin{array}{c}-3.5629^{* * *} \\
{[-36.08]}\end{array}$ & $\begin{array}{c}-3.5614^{* * *} \\
{[-36.06]}\end{array}$ & $\begin{array}{c}-3.5981^{* * *} \\
{[-36.63]}\end{array}$ & $\begin{array}{c}-3.6395^{* * *} \\
{[-37.09]}\end{array}$ \\
\hline$F O$ & & $\begin{array}{l}-0.0000 \\
{[-0.79]}\end{array}$ & $\begin{array}{l}0.0000 \\
{[0.44]}\end{array}$ & $\begin{array}{l}0.0000 \\
{[0.03]}\end{array}$ \\
\hline GDP & & & $\begin{array}{c}-0.1355^{* * *} \\
{[6.30]}\end{array}$ & $\begin{array}{c}-0.1656^{* * *} \\
{[-7.45]}\end{array}$ \\
\hline$C A B$ & & & & $\begin{array}{c}-0.0178^{* * * *} \\
{[-5.08]}\end{array}$ \\
\hline$R^{2}$ & 0.4741 & 0.4742 & 0.4823 & 0.4871 \\
\hline
\end{tabular}

Additionally, with respect to control variables, we make following observations. We find $E R, G D P$, and $C A B$ has a negative and statistically significant effect on exchange rate volatility. Our findings are consistent with different model specifications. The only exception is $F O$ which is found to be statistically insignificant. This implies that $F O$ has no significant impact on exchange rate volatility. The relatively small portion of $F O$ compared to the $T O$ could be the reason for this statistically insignificant result. Finally, it is also worth noting that the R-squared statistics are found to be greater when control variables are included in the model compared to the benchmark model. For instance, the R-squared statistics is reported highest in the model which includes all four control variables. The R-squared statistics increased from $22 \%$ in the benchmark model to $49 \%$ in a model with all four control variables.

Next, we conduct results by disaggregating $T O$ and $F O$ into two categories. $T O$ is divided by into two groups, namely export and import of goods $(G O)$ and 
export and import of services (SO) whereas $F O$ is divided into two categories namely equity and non-equity related foreighn liabilities. We report these results in Panel A of Table 6. We find that both GO and SO has a negative and statically significant effect on exchange rate volatility. This implies that TO either taken as aggregate or diaggregate in terms of goods and services, has a consistent effect on exchange rate volatility. Additionally, the two disaggregate categories of FO remain statistically insignificant which is consistent with our earlier findings. In the case of remaining three control variables (namely $E R, G D P$, and $C A B$ ) our findings remain same.

Table 6.

\section{Results Based on Different Trade Structures}

This table report results based on two different trade structures. Panel A report results for an empirical model which is augmented with four additional variables, the composition of trade openness (namely Good Openness (GO) and Services Openness (SO)) and the composition of financial openness (namely equity and non-equity foreign liability variables). Panel B report results for the empirical model where we replace the SO with non-manufactured trade services openness (Non-M). We report estimated coefficients and its corresponding t-statistics in parenthesis. ${ }^{* * *}$, ***, and ${ }^{*}$ denote statistical significance at the $1 \%, 5 \%$, and $10 \%$, respectively.

\begin{tabular}{|c|c|c|}
\hline & Panel A & Panel B \\
\hline Constant & $\begin{array}{c}3.6768^{* * *} \\
{[12.28]}\end{array}$ & $\begin{array}{c}3.7024^{* * *} \\
{[12.39]}\end{array}$ \\
\hline GO & $\begin{array}{c}-0.0042^{* * *} \\
{[-5.03]}\end{array}$ & $\begin{array}{c}-0.0040^{* * *} \\
{[-4.93]}\end{array}$ \\
\hline SO & $\begin{array}{c}-0.0057^{* * *} \\
{[-3.89]}\end{array}$ & \\
\hline Non-M & & $\begin{array}{c}-0.0064^{* * *} \\
{[-3.91]}\end{array}$ \\
\hline$M S V$ & $\begin{array}{c}0.1008^{* * *} \\
{[14.54]}\end{array}$ & $\begin{array}{c}0.1001^{* * *} \\
{[14.43]}\end{array}$ \\
\hline$E R$ & $\begin{array}{c}-3.7031^{* * *} \\
{[-37.60]}\end{array}$ & $\begin{array}{c}-3.6984^{* * *} \\
{[-37.70]}\end{array}$ \\
\hline Equity & $\begin{array}{c}-0.0002 \\
{[-1.12]}\end{array}$ & $\begin{array}{c}-0.0020 \\
{[-1.06]}\end{array}$ \\
\hline Non-equity & $\begin{array}{c}-0.0000 \\
{[-0.70]}\end{array}$ & $\begin{array}{c}-0.0000 \\
{[-0.61]}\end{array}$ \\
\hline$G D P$ & $\begin{array}{c}-0.1638^{* * *} \\
{[-7.26]}\end{array}$ & $\begin{array}{c}-0.1622^{* * *} \\
{[-7.22]}\end{array}$ \\
\hline$C A B$ & $\begin{array}{c}-0.0179^{* * *} \\
{[-4.95]}\end{array}$ & $\begin{array}{c}-0.0181^{* * *} \\
{[-4.99]}\end{array}$ \\
\hline$R^{2}$ & 0.4915 & 0.4916 \\
\hline
\end{tabular}

In addition, according to Landefeld (1978), services trade and manufacturing trade are intricately linked, and therefore, it is assumed that services trade are complement rather than a substitute for manufacturing trade sector. Thus, higher export of manufactured goods will also increase services trade, particularly the cost related to shipping activities such as freight, equipment maintenance, and insurance. Considering this link between services trade and manufactured goods trade, we re-estimate the model by incorporating non-manufactured related services openness (includes travel and passenger transport services, ICT services, 
intellectual property charges, financial services, government procurement services, and construction services) as a proxy for SO. We report these results in Panel B. Our results remain same and we do not observe any significant change in any of the estimated variables. As expected, the non-manufactured related services trade openness has a negative and statistically significant effect on the exchange rate volatility.

\section{Robustness Test}

To check the robustness of our findings, we divide our data sample into various categories and estimate the following regression model:

$$
\begin{aligned}
R E R V_{i t}=\alpha_{0} & +\beta_{1} G O_{i t}+\beta_{2} \text { non }-M_{i t}+\beta_{3} M S V_{i t}+\beta_{4} E R_{i t}+\beta_{5} \text { equity }_{i t} \\
& +\beta_{6} \text { non }- \text { equity }_{i t}+\beta_{7} G D P_{i t}+\beta_{8} C A B_{i t}+\varepsilon_{i t}
\end{aligned}
$$

Once again, we have replaced TO with GO and non-manufactured related trade services openness, depicted by non- $M$. The control variable, FO is replaced by equity related foreign liabilities, denoted by equity, and non-equity related foreign liabilities, represented by non-equity in the above model. The remaining varaibles are defined earlier in Section III.

First, we categorise 52 countries into two income-based groups, namely HI countries and MI countries and report results in Panel B of Table 7. Second, we divide 52 countries into two groups according to the classification of with and without the implementation of Inflation Targeting Framework (ITF). In other words, 52 countries are divided into following two groups: (i) ITF countries (25 countries with the implementation of ITF, namely Australia, Brazil, Canada, Chile, Colombia, Czech Republic, Hungary, Iceland, India, Indonesia, Japan, Mexico, New Zealand, Norway, Peru, Philippines, Poland, Romania, Russia, South Africa, South Korea, Sweden, Thailand, Turkey, and United Kingdom) and (ii) non-ITF countries (27 countries without the implementation of ITF, namely Argentina, Austria, Belgium, Bulgaria, China, Croatia, Cyprus, Denmark, Estonia, Finland, France, Germany, Greece, Ireland, Israel, Italy, Latvia, Lithuania, Malaysia, Netherlands, Portugal, Saudi Arabia, Slovakia, Slovenia, Spain, Switzerland, and United States). These results are reported in Panel C. Finally, we divide our data sample period into two groups in order to eliminate the effect of the Global Financial Crisis (GFC). More specifically, we divide our data sample into pre-GFC (2005Q01 to 2007Q02) and post-GFC periods (2010Q01 to 2019Q01) and report results in Panel D. 


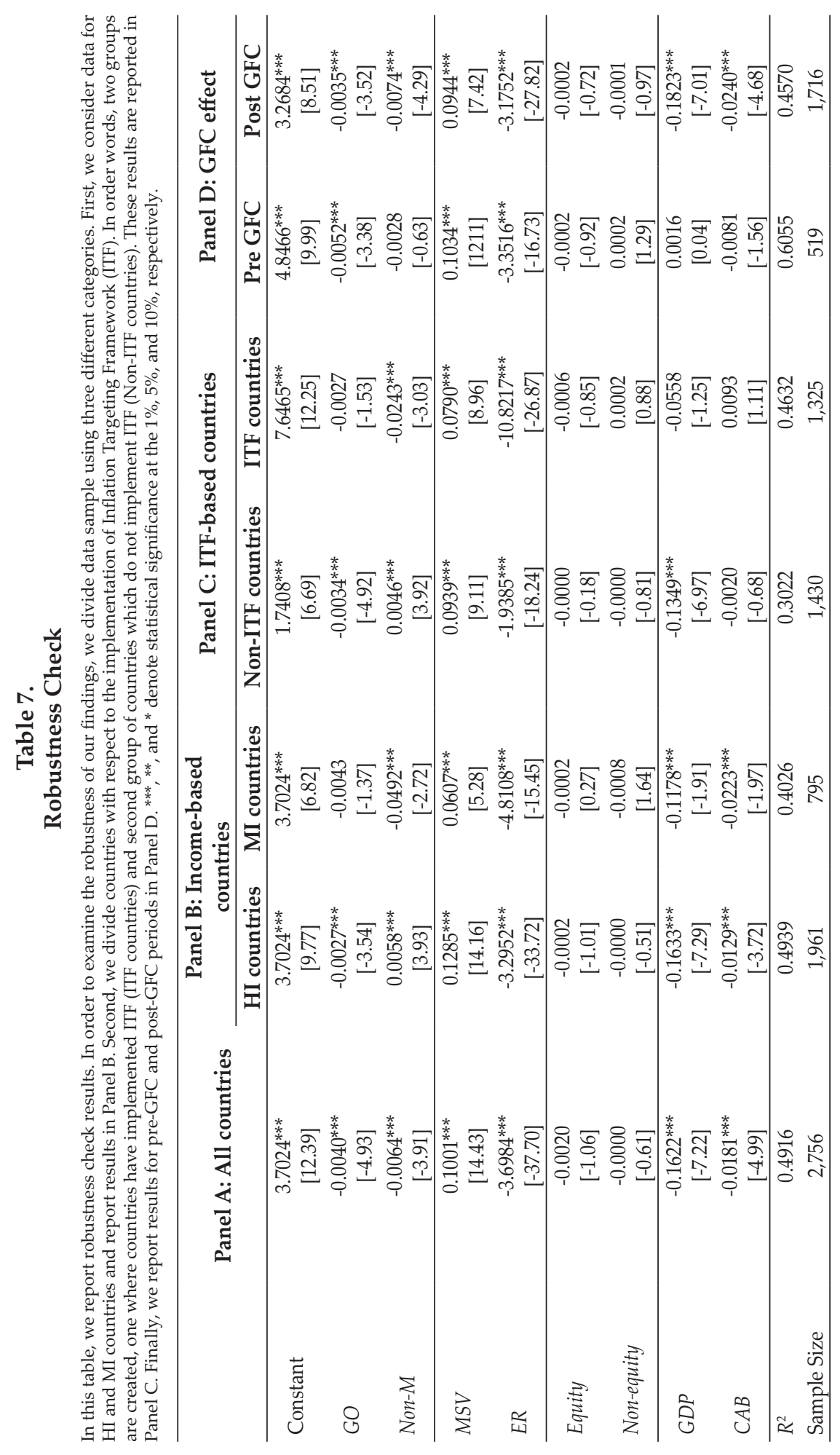


First, we read results from Panel B. Our results remain same irrespective of considering two income-based groups. The only exception is the GO, which is found to be statistically insignificant in the case of MI countries. This indicates that $G O$ has a statistically significant effect on exchange rate volatility only in the case of HI countries. Second, we read results from Panel B. here we observe that $G O$ is statistically insignificant in the case of ITF countries. This implies that GO has no significant effect on exchange rate volatility of those countries which has implemented ITF, however, it has a negative and significant effect on exchange rate volatility of those countries without ITF. Finally, we read results from Panel C. Here we observe that non-M has an insignificant effect on exchange rate volatility prior to the GFC period, however, during post-GFC period, the same has statistically significant and negative effect on exchange rate volatility of all countries.

Our findings with respect to the second main variable, $M S V$, remains same irrespective of different sample groupings. We find strong evidence that $M S V$ has a statistically significant and positive effect on exchange rate volatility irrespective of different model specifications and different sample categories considered in the study.

\section{CONCLUSION}

In this study, we examine the relationship between trade openness and exchange rate volatility for a panel of 52 countries. Our data spans the period 2005Q1 to 2019Q1. Using different estimation techniques, we document that TO has a negative and statistically significant effect on exchange rate volatility. In addition, we also document that the second main explanatory variable, the money supply shock, has a positive and statistically significant effect on exchange rate volatility.

Additionally, we have conducted analysis using number of robustness approaches. First, we extend our benchmark model by including four different control variables, namely $E R, G D P, F O$, and $C A B$. Second, we consider taking disaggregate components of $T O$, namely $S O$ and GO. Third, we disaggregate $F O$ into two more components, namely equity and non-equity and replace $\mathrm{SO}$ with non- $M$ trade openness. Irrespective, of using different proxies and components of $T O, F O$, and $S O$, our findings remain unchanged.

Furthermore, we divided countries into: (i) two income level groups, namely $\mathrm{HI}$ countries and MI countries and (ii) countries with (ITF-countries) and without (non-ITF countries) inflation targeting frameworks; and finally, we conduct analysis during pre-GFC and post-GFC periods to control for GFC effects. Our findings remain unchanged irrespective of different grouping of countries and data samples. 


\section{REFERENCES}

Aghion, P., P. Bacchetta, R., Ranciere, \& Rogoff, K. S. (2009). Exchange Rate Volatility and Productivity Growth: The Role of Financial Development. Journal of Monetary Economics

Balaguer, J., \& Cantavella-Jorda, M. (2002). Tourism as a Long-Run Economic Growth Factor: the Spanish Case. Applied economics, 34, 877-884.

Bergin, P. R., \& Feenstra, R. C. (2001). Pricing-to-market, Staggered Contracts, and Real Exchange Rate Persistence. Journal of international Economics, 54, 333-359.

Bleaney, M. (2008). Openness and Real Exchange Rate Volatility: In Search of an Explanation. Open Economies Review.

Bleaney, M., \& Greenaway, D. (2001). The Impact of Terms of Trade and Real Exchange Rate Volatility on Investment and Growth in Sub-Saharan Africa. Journal of development Economics, 65, 491-500.

Broda, C., \& Romalis, J. (2011). Identifying the Relationship Between Trade and Exchange Rate Volatility. In Commodity Prices and Markets, 79-110. University of Chicago Press.

Calderón, C., \& Kubota, M. (2018). Does Higher Openness Cause More Real Exchange Rate Volatility?. Journal of International Economics, 110, 176-204.

Çalışkan, U., Saltik, I. A., Ceylan, R., \& Bahar, O. (2019). Panel Cointegration Analysis of Relationship between International Trade and Tourism: Case of Turkey and Silk Road Countries. Tourism Management Perspectives, 31, 361-369.

Dornbusch, R. (1976). Expectations and Exchange Rate Dynamics. Journal of Political Economy.

Grydaki, M., \& Fountas, S. (2009). Exchange Rate Volatility and Output Volatility: A Theoretical Approach. Review of International Economics, 17, 552-569.

Hau, H. (2000). Exchange Rate Determination: The Role of Factor Price Rigidities and Nontradeables. Journal of International Economics.

Hau, H. (2002). Real Exchange Rate Volatility and Economic Openness: Theory and Evidence. Journal of Money, Credit, and Banking.

Khan, H., Toh, R. S., \& Chua, L. (2005). Tourism and Trade: Cointegration and Granger Causality Tests. Journal of Travel Research, 44, 171-176.

Klau, M. (2006). The New BIS Effective Exchange Rate Indices 1. BIS Quaterly Review.

Kulendran, N., \& Wilson, K. (2000). Is There a Relationship Between International Trade and International Travel?. Applied Economics, 32, 1001-1009.

Landefeld, J. S. (1987). International Trade in Services: Its Composition, Importance and Links to Merchandise Trade. Business Economics, 25-31.

Lundberg, D. E., Krishnamoorthy, M., \& Stavenga, M. H. (1995). Tourism Economics. John Wiley and sons.

Mattoo, A., Rathindran, R., \& Subramanian, A. (2001). Measuring Services Trade Liberalization and its Impact on Economic Growth: An Illustration (Vol. 2655). World Bank Publications.

McKinnon, R. I., Radcliffe, C., Tan, K. Y., Warga, A. D., \& Willett, T. D. (1984). International Influences on the US economy: Summary of an Exchange. The American Economic Review, 74, 1132-1134.

Meese, R. A., \& Rogoff, K. (1983). Empirical Exchange Rate Models of the Seventies. Do They Fit out of Sample?. Journal of International Economics. 
Morana, C. (2009). On the Macroeconomic Causes of Exchange Rate Volatility. International Journal of Forecasting, 25, 328-350.

Obstfeld, M., \& Rogoff, K. (1995). Exchange Rate Dynamics Redux. Journal of Political Economy.

Obstfeld, M., and Rogoff, K. (1996). Foundations of International Macroeconomics. The MIT Press.

Rogoff, K. (1999). Monetary Models of Dollar/Yen/Euro Nominal Exchange Rates: Dead or Undead? The Economic Journal, 109, F655-F659.

Salmani, B., Panahi, H., \& Razzaghi, S. (2014). Assessing the Dynamic Economic Impact of Tourism for OIC Members. World Applied Sciences Journal, 32, 10981105.

Seetanah, B. (2011). Assessing the Dynamic Economic Impact of Tourism for Island Economies. Annals of Tourism Research, 38, 291-308.

Servén, L. (1998). Macroeconomic Uncertainty and Private Investment in Developing Countries: An Empirical Investigation. Available at SSRN 597249.

Taylor, Mark P. (1995) The Economics of Exchange Rates. Journal of Economic Literature. 